\title{
CRIAÇÃO ÉTICO-POÉTICA EM ÚLTIMAS COMPOSICIONES (1966), DE VIOLETA PARRA: OPÇÃO DECOLONIAL
}

\author{
ETHICAL-POETIC CREATION IN ÚLTIMAS \\ COMPOSICIONES (1966), BY VIOLETA PARRA: \\ DECOLONIAL OPTION
}

\author{
Patricia Virginia Cuevas Estivil ${ }^{1}$ \\ [https://orcid.org/0000-0002-0079-1864] \\ Lourdes Kaminski Alves ${ }^{2}$ \\ [https://orcid.org/0000-0001-5108-4927] \\ DOI: 10.30612/raido.v15i38.14895
}

RESUMO: Neste artigo, procuramos refletir sobre a proposta estética da poeta, compositora e artista plástica chilena, Violeta Parra, cuja vida e obra foi marcada pelo desejo de tornar conhecida a arte popular de seu país, sobretudo, aquela de raiz mapuche, que pode ser encontrada no álbum musical Ủltimas Composiciones (1966). Tal opçâo de criaçăo ético-poética contempla um trabalho de decolonizaçâo cultural epistêmica, cuja elaboraçăo faz transparecer aspectos de uma linguagem artística híbrida, transcultural e fronteiriça. Encontram-se nas composiçōes poético-musicais, exemplos da valoraçăo da tradiçăo indígena, recorrendo ao lamento mapuche, a rogativa e a invocativa como estratégias de oposiçáo ao colonialismo, ao capitalismo e ao patriarcalismo o que referencia uma opçăo decolonial da autora.

Palavras-chave: Violeta Parra: Últimas Composiciones: canto mapuche: decolonizaçâo epistêmica.

ABSTRACT: In this article, we seek to reflect on the aesthetic proposal of the Chilean poet, composer and plastic artist, Violeta Parra, whose life and work was marked by the desire to make her country's popular art known, especially the one with Mapuche roots, which can be found in the musical album Últimas Composiciones (1966). Such option of ethical-poetic creation contemplates a work of epistemic cultural decolonization, whose elaboration reveals aspects of a hybrid, transcultural and border artistic language. Examples of the valuation of indigenous tradition can be found in the poetic-musical compositions, using the Mapuche lament, the rogative and the evocative as opposition strategies to colonialism, capitalism and patriarchy, which refer to a decolonial option of the author.

Keywords: Violeta Parra:Últimas Composiciones: mapuche chant: epistemic decolonization.

\footnotetext{
1 Universidade Estadual do Oeste do Paraná (UNIOESTE)

2 Universidade Estadual do Oeste do Paraná (UNIOESTE)
} 


\section{INTRODUÇÃO}

Volver a los diecisiete,

después de vivir un siglo,

es como descifrar signos,

sin ser sabio competente.

Volver a ser de repente,

tan frágil como un segundo,

volver a sentir profundo

como un niño frente a Dios.

Eso es lo que siento yo,

en este instante fecundo.

[...]

(PARRA, apud, MIRANDA, 2014, p. 45)

Neste texto ${ }^{3}$ propomos uma reflexăo, a partir dos poemas cançôes que se encontram no álbum musical Últimas Composiciones (1966), de Violeta Parra (1917-1967), cujas composiçôes denotam elementos da cultura mapuche na obra da artista plástica, pintora, escultora, poeta, folcloróloga e compositora chilena.

Violeta foi pesquisadora da tradiçăo popular e a primeira mulher latino-americana a expor sua obra no Museo de Louvre em Paris. Escreveu três livros representativos da arte popular e Fundou o Museo do Folclore em Concepción - Chile. Foi convidada a participar de diversos encontros de escritores para proferir conferências sobre a tradiçăo popular chilena, também, convidada a expor sua obra na Feira Nacional e Internacional de Artes Plásticas, levando a arte popular a todos os cantos do país e da Europa.

O que teria motivado Violeta Parra a resgatar, recopilar e editar as obras inéditas da tradiçăo popular e indígena? A produçăo Últimas Composiciones (1966) faz parte de um momento de produçâo em que Violeta demonstra, talvez, de forma mais evidente, o despertar de uma consciência política, na perspectiva da decolonizaçâo do pensamento crítico e criativo.

A partir de 1952, impulsionada pelo irmáo e poeta Nicanor Parra, Violeta começou a percorrer diferentes zonas rurais e suburbanas, pesquisando, resgatando e recopilando a poesia e o canto popular dos mais recônditos lugares do seu país, experiência que sem dúvida repercutiu na sensibilidade artística, acrescentando elementos populares a seus poemas cantados.

Nessa etapa de sua produçáo, Violeta desenvolve uma arte poético-musical de pulsăo amorosa, segundo estudos de Paula Miranda (2014), produçáo que torna a obra de Violeta conhecida em diversos países.

3 Parte deste texto integra o projeto de pesquisa intitulado Imagens Poéticas e Decolonizaçāo na Obra de Violeta Parra, de Patricia Virginia Cuevas Estivil, desenvolvido no Programa de Pós-graduaçấo em Letras da Universidade Estadual do Oeste do Paraná - UNIOESTE. Disponível em: http://tede.unioeste. br/handle/tede/3669. 
Muitas de suas Últimas Composiciones (1966) foram escritas em décimas, a exemplo de "Gracias a la vida" e "Volver a los diecisiete", mas pautadas na compreensâo do mundo a partir do olhar indígena. Esses últimos poemas musicados, escritos por Violeta expressam uma reflexâo filosófica sobre o amor carregada de metáforas com elementos da natureza. "La unión de factores cultos con otros propiamente folclóricos entrega una canción de indudable contenido poético-dramático y una de las más bellas composiciones de la autora". (PIN̂A, 1978, p. 151). A fusăo entre o culto e o popular é parte importante da gênese de sua obra.

A artista reconhece que as composiçōes "Qué he sacado com quererte", "Gracias a la vida", "Volver a los 17", “Run-Run se fue pa'l norte", do álbum Últimas Composiciones (1966), săo poemas de rara beleza: "desculpa que diga que estas obras son lindas, pero es que yo soy huasa" (PARRA,1966 apud SUBERCASEAUX; STAMBUK; LONDOÑO, 1978, p. 35). Nesses textos há um olhar profundo sobre o universo, que transcende como terceira vertente da tradiçâo popular oral - a vertente ancestral dos povos originários - de forma vital, e se inscreve como uma arte reflexiva, feita para ser ouvida, que busca libertar o homem de suas amarras colonialistas.

Gastón Soublette, musicista, pensador e esteticista da arte chilena, amigo e estudioso da obra musical de Violeta Parra, expressa neste fragmento:

Violeta formó discípulos. Entre ellos, Héctor Pavez y Gabriela Pizarro se destacan como grandes exponentes, donde se puede apreciar los rasgos de su escuela. Antes que nada, se trata del repertorio. En sentido especial, para destacar a los informantes del pueblo capaces de transmitir aquellos ejemplares de la tradición poético-musical chilena, de raíces más antiguas. En seguida, se trata de un estilo de canto, de emisión más continua y homogénea, y casi sin vibrato. Justamente lo que ha caracterizado el tipo de voz apropiado para el canto de todas las auténticas tradiciones folcóricas del mundo, incluidas las de África. (SOUBLETTE, apud PARRA, Isabel, 2009, p.33).

Os poemas cantados de violeta Parra contêm temas vitais que partem do local para se expandir de modo intercultural. Esse anseio de fazer pensar, provocar a reflexăo, como um ato de autoconhecimento profundo das capacidades da alma e do corpo, vem da segunda etapa de mudanças na obra de violeta Parra, provocada por sua convivência com o povo mapuche, possuidor de um saber ancestral, recolhido na voz de caciques, longkos e de machis, participando de rogativas e machitun, que lhe ensinaram a compreender a sabedoria contida no canto mapuche.

Os textos selecionados do álbum musical Últimas Composiciones (1966) apresentam características de uma arte fundada nos princípios da decolonizaçâo artística, pelo fato de se afastarem da norma, e por introduzirem uma crítica que expressa, pontos de vista indicadores de um giro, uma ruptura na forma de fazer arte.

\section{LAMENTO MAPUCHE: "QUÉ HE SACADO COM QUERERTE"}

O contato com a arte mapuche deu vitalidade à obra de Violeta, que em seu anseio por afastar o seu trabalho artístico da ideologia colonialista da sociedade burguesa vigente na época em que a artista viveu, procura se refugiar em saberes mais próximos 
do povo e da sua própria realidade. "Qué he sacado com quererte" é um exemplo desta vitalidade. A artista escreve em versos, na forma de lamento mapuche, o seu próprio lamento. Paula Miranda (2017), explica em seu livro Violeta Parra en el Walmapu, que o povo indígena fazia da arte uma forma de realizar algum fato social. Nenhum poema era cantado ou tocado um instrumento, apenas pelo fato de fazer arte, e sim, como uma necessidade material de vida. Agradecer, rogar a Deus, chorar um amor perdido ou uma morte, celebrar um nascimento, fazer dormir os filhos eram fatos que requeriam rituais, cançōes e instrumentos próprios.

Neste poema cançăo, Violeta se lamenta de ter amado tanto alguém que tirou-lhe a alegria de viver, como se pode observar nos versos a seguir:

\author{
Qué he sacado com quererte \\ ¿Qué he sacado con la luna; ayayay \\ que los dos miramos juntos? ayayay \\ ¿Qué he sacado con los nombres, ayayay \\ estampados en el muro? ayayay \\ Como cambia el calendario, ayayay \\ cambia todo en este mundo.ayayay

\section{Ayayay, ay, ay} \\ ¿Qué he sacado con el lirio, ayayay \\ que plantamos en el patio? ayayay \\ No era uno el que plantaba, ayayay \\ eran dos enamorados. ayayay \\ Hortelano, tu plantío, ayayay \\ con el tiempo no ha cambiado. Ayayay \\ [...]. (PARRA, 1966).
}

Trata-se de um lamento por uma perda. Em entrevista cedida à Radio Universidad de Chile, sobre a relaçáo de Violeta com o canto mapuche, os entrevistadores destacam que:

Violeta Parra, le canta a la vida y el canto mapuche es un canto a las cosas de la vida: se le canta al trabajo, al amor, a la guagua, a las penas de la viudez [...]. Todo lo que se hace se canta, porque el canto es una forma de socialización con el otro y con la naturaleza. (MIRANDA; LONCON; RAMAY, 2017).

Esta característica do canto mapuche, o lamento, seja na temática, seja na forma, está presente na composiçấo de "Qué he sacado con quererte". Violeta recolhe a palabra do canto do povo e a comunica em suas cançôes. Tal procedimento também é percebido em outras composiçóes do álbum, a exemplo de "Arriba quemando el Sol" e "Arauco tiene una pena".

La influencia de la música mapuche en la obra de Violeta Parra se evidencia en sus ritmos, en la utilización de instrumentos como el kultrun y en los temas que aborda. El guillatún o Arauco tiene una pena son ejemplo de ello. Del mismo modo, Qué he sacado con quererte es interpretado como un lamento mapuche (MIRANDA; LONCON; RAMAY, 2017). 
O canto mapuche toma conta da obra artística de Violeta Parra. E essa representaçăo da vida é poesia que flui transparente e vital, revigora o fazer artístico por meio de uma poética decolonial, que retoma o saber de povos ancestrais.

\section{A ROGATIVA "GUILLATUN" E O CHAMANENTO "ARAUCO TIENE UNA PENA"}

Procurar compreender a obra de Violeta Parra, a partir de sua tomada de consciência sobre o valor das culturas ancestrais, responde ao nosso questionamento sobre o que teria motivado Violeta Parra a recopilar e editar as obras inéditas da tradiçâo popular e indígena. É importante observar que a autora nâo agiu do mesmo modo diante das obras resgatadas da tradiçăo hispânica, nem diante das pertencentes à tradiçâo indígena. As primeiras, ela recopilou e editou em vários discos que resultou no livro intitulado Cantos Folclóricos Chilenos (1979), publicados depois de sua morte. Entretanto, das pesquisas e gravaçôes que realizou junto à coletividade indígena, ela incorporou outra perspectiva, incluindo aspectos da filosofia de vida que pertence à sabedoria mapuche. Violeta Parra conseguiu captar o sentir dessa cultura silenciada, mas năo extinta, no processo colonialidade/modernidade.

Configura-se aí, um gesto advindo de uma consciência decolonial e ao sentido político que esta concepçáo contém. Os dois poemas cançôes "Guillatun" e "Arauco tiene una pena" sáo provas desta tomada de consciência. O poeta chileno mapuche, Elicura Chihuailaf nos explica o que representa para o povo mapuche o Guillatun:

El Guillatun que es una manifestación espiritual en la que la comunidad rinde tributo - mediante ofrendas y rogativas - al espíritu Azul; el Espíritu Poderoso en sus cuatro manifestaciones: Elmapun / Gvenmapu; Elchen / Gvnechen. Como Creador y Sostenedor de la Tierra y de la gente. Es una ceremonia que dura dos días. Es dirigida por el Lonko Genpin (excepcionalmente la Machi), con el apoyo de una autoridad ayudante llamada Nizol. En él participan todas las familias de una comunidad; cada una de ellas invita a sus parientes y amigos. Se acuerda también la invitación a otras comunidades. [...]. Durante el Guillatun se hacen rogativas, se ofrecen productos naturales - cántaros de muzay, canastos con semillas, frutos, espigas, carnes - que son depositados en el Rewe. (CHIHUAILAF, 1999, p.75)

É nessa manifestaçăo espiritual que Violeta encontra seu canto, na profunda sabedoria mapuche, por entender que esta sabedoria se sobrepóe ao saber ensinado como única verdade da cultura Ocidental, de homens brancos, civilizados, que utilizaram a religiâo para fins humanos de ambiçâo e poder. Violeta se posiciona na compreensâo do universo como dualidade: a vida e a morte. A chuva forte que destrói e a chuva suave que traz a vida. $O$ positivo náo pode existir sem o lado negativo, de tal forma que os modelos sociais e culturais de crenças e religiōes aparecem em seus poemas, tanto na forma de conteúdos quanto nos elementos estruturantes.

Millelche está triste con el temporal

Los trigos se acuestan en ese barrial [...]

Camina la machi para el guillatun

Chamal y rebozo, trailonco y cultrún, 
Y hasta los enfermos de su machitún,

Aumentan la fila de aquel guillatún,

De aquel guillatún, de aquel guillatún [...]

Se juntan los indios en un corralón,

Con los instrumentos rompió una canción,

La machi repite la palabra "Sol"

Y el eco del campo le sube la voz

Le sube la voz, le sube la voz.

El rey de los cielos muy bien escuchó

Remonta los vientos para otra región,

Deshizo las nubes, después se acostó

Los indios lo cubren con una oración

Con una oración, con una oración.

Arriba está el cielo brillante de azul,

Abajo, la tribu al son del cultrún

Le ofrecen del trigo su primer almud

Por boca de un ave llamada avestruz

Llamada avestruz, llamada avestruz.

(PARRA,1966)

O sentido do lamento crítico está na linguagem com que Violeta instala sua interaçăo com a cultura mapuche, recuperando um elemento fundamental, o sentimento de coletividade, com que os povos autóctones trabalham por um objetivo comunitário, neste caso, salvar a plantaçăo.

A fé, um elemento importante nas culturas originárias, é motor propulsor das suas crenças, a Machi dirige a rogativa com o kultrun ${ }^{4}$. Em suas máos, o gesto é muito significativo para o povo mapuche, "La Machi, al tener asido en sus manos el kultrun, está sosteniendo simbólicamente al universo, o como diria cualquiera, sostiene al mundo en un puño". (CHIHUAILAF, 1999, p.34). Tocar o kultrun na cultura indígena representa a invocaçâo de toda a estrutura do universo em seus quatro níveis: Elmapun / Gvenmapu; Elchen / Gvnechen. A rogativa deverá chegar aos ouvidos do Deus dos céus que age em favor dessa comunidade, reorganizando os ventos e as chuvas para que nâo destruam suas plantaçōes. Representa o gesto de agradecimento, oferendas a fé no Espírito Azul, referência à cultura mapuche.

No "Guillatun" e em "Arauco tiene una pena", Violeta se posiciona contra as formas simbólicas estabelecidas pelo Ocidente, por essas representarem a vigência de um discurso excludente e autoritário, que se reflete na consciência dos povos latino-americanos, a exemplo do desrespeito com a forma de ser, pensar e viver do

4 Kultrun é um instrumento musical dividido em quatro partes que representam as dimensōes do universo, usado pelo Xamá para dar ritmo à cerimônia Mapuche. 
indígena que habita em reduçóes. Por meio de sua arte, Violeta Parra opóe-se ao discurso preconceituoso da colonialidade/modernidade. A permanência da cultura do colonizador dominando a consciência dos povos colonizados degrada a autoconsciência destes povos de suas próprias formas culturais, age como força corrosiva, que destrói qualquer compreensăo que possa superar os domínios da colonizaçăo, reforçado pelas formas simbólicas burguesas, que transformam o colonizado em ser dependente das antigas metrópoles.

O que significa ser o resultado de um processo de colonizaçâo, neste caso? Entre outras perdas culturais, significa a perda da compreensăo da relaçăo do homem com a natureza, năo somente desta geraçăo e de geraçóes passadas, também das geraçóes futuras. A instauraçăo do colonialismo na América tornou o homo sapiens incapaz de fazer correspondências entre o visível e o invisível ao olho humano, incapaz da percepçăo do universo, do cosmos que habita dentro de cada ser humano. As palavras de reciprocidade entre o universo e o homem, escutando as palavras da Machi, movendo as nuvens, săo elementos mágicos do mito e da lenda, da compreensăo do mundo como um todo que dialoga e se entende por meio da palavra. É a palavra mapuche que Violeta resgata nessa rogativa. Elicura Chihuailaf, referindo-se às palavras de seus antepassados chama atenção:

Nos dicen: La gente, el ser humano, viaja por la vida con un mundo investido de gestualidad que se expresa antes que el murmullo inicial entre el espíritu y el corazón sea realmente comprendido. Poco a poco dicho murmullo se transforma en lenguaje. [...] Así, nuestra incipiente sabiduría nos revela que la vida, que el ser humano, que la Tierra y el universo son la manifestación "real" de la dualidad. En el mirar aquí y hacia arriba comprobamos que somos - cada cual - constelaciones del cosmos exterior e interior, somos un cuerpo que, buscando su correspondencia con lo visible y lo invisible, proyecta su energía - su espíritu - hasta lo inimaginable, aferrados a la senda marcada por puntos luminosos - también externos e internosllamados estrellas. Mas hoy hay quienes en la ciudad me dicen que no escriba la palabra antepasados, ni la palabra antiguos, ni la palabra mayores. Y yo me digo y les digo: el ser humano viaja por la vida con un mundo investido de gestualidades que se expresa antes que el murmullo inicial entre el espíritu y el corazón sea realmente comprendido. (CHIHUAILAF, 1999, p.66-67).

Isto nos leva a pensar que, o que mais convinha às Metrópoles era manter silenciadas as vozes culturais dos povos que haviam colonizado, anulando sua história, com o intuito de ocultar, quase que totalmente, sua compreensâo de mundo, seus costumes, organizaçăo política, religiăo e, sobretudo a língua e os valores que esta contém. O silenciamento visa evitar que o homem compreenda a vida desde seu exterior/interior. Trata-se do silenciamento de elementos fundantes da formaçăo cultural de uma tradiçâo, por serem elementos constitutivos da identidade, construídos historicamente para dar resposta às necessidades específicas e ancestrais dos povos indígenas na América Latina.

Os poemas cançôes representam a açăo da força anticoercitiva a qual se localiza justamente, no momento histórico em que Violeta Parra, paralelamente a este processo de silenciamento e destruiçấo da tradiçâo popular, procura resgatá-la, desenterrando a obra poético-musical que permanecia inédita no espaço rural, trazendo-a de volta à vida. 
De acordo com Juan André Piña:

Hay que irse con cuidado con esta Violeta Parra. Desdeñada, ignorada, esquivada como maldición Durante su vida, ahora ya traspasó definitivamente nuestras fronteras y sus canciones y sus arpilleras andan con motor propio a través de todo el mundo. Seguramente ella supo ver más allá, mucho más allá que los hombres de su tiempo. Después se hablará de la fundación de nuestra América basándose en los Historiadores de las Indias, en Martín Fierro, en el Canto General, en la Nueva Novela Latinoamericana y en las Décimas de Violeta Parra. (PINAA, 1978, p.14-15).

O trabalho que Violeta realiza, de desenterrar a memória cultural do povo chileno, num primeiro momento, pretendia centrar-se nas antigas cançóes campesinas inéditas de transmissáo oral que pertenciam aos cantores populares hispânicos. Tais cantores acabariam relacionando-se e intercambiando os respectivos modos de ver o mundo, deseducando, educando e reeducando os povos originários dessa regiăo da América Latina: os mapuches, os quais adotariam seus costumes, aprenderiam sua língua e entoariam seus cantos, dentre eles, o canto a lo divino, com o qual, através dos tempos, se vigoraria o processo de evangelizaçâo, começado pelos jesuítas, dominicanos e franciscanos nos tempos da Colônia. Referimo-nos, neste caso, as formas simbólicas Ocidentais, como ferramentas de sustentaçâo de estereótipos culturais, que em seu interior contém uma violência de superioridade que alimenta a rede de argumentos do sistema binarista colonial do tipo aceitaçăo-exclusáo.

No sistema colonialista chileno, o indígena e o cantor popular como campesino arcaico foram colocados à margem da sociedade moderna/colonial, porquanto a tradiçăo popular, à que ambos pertencem, nâo possui os traços necessários para a aceitaçấo e integraçăo dentro do mundo criado pelo colonizador, consequência do processo de modernidade/colonialidade, sendo que a exclusăo foi seu único destino.

Para Walter Mignolo (2008), este processo náo somente afeta países territorialmente, a humanidade personificada pelo colonizador por suas próprias regras, haverá de desatar cada nó dessa rede colonial, transformando a açấo decolonizadora num ponto de desapego e abertura que reintroduza os elementos que, no período colonial, sofreram um processo de silenciamento. Martin Lienhard (2011) denomina este processo de "ocultamento da palavra outra". Processo que incide na língua, na memória coletiva, na subjetividade, na economia e na organizaçăo política, social e cultural dos povos originários da América e posteriormente, do povo mestiço latino americano. Realizar o resgate da memória coletiva desse povo significa se aproximar do lugar onde os fatos aconteceram. Permite-nos ler a história "desde acá," (MIGNOLO, 2008), em sua própria e particular maneira de ser e interpretar os símbolos da vida.

Neste contexto, o próprio dos povos colonizados, encontra seu lugar congruente com a vida que, como cultura popular, nasce da necessidade de dar respostas a problemas e questionamentos, colocados pela própria existência, que se veem coagidos a deixar, para seguir as "regras de dominaçăo" de uma cultura dita universal. Esta nasceu pela necessidade de satisfazer e dar repostas ao povo europeu. Isto, ironicamente, marca duas bases de análise, a genealogia do pensamento Ocidental, que impóe estrategicamente seus símbolos tomando parte do que é essencial para 
os povos colonizados, mas deslocado do patrimônio cultural dos povos originários, já que responde a outra lógica, que dita outra ordem social. Como expressa Elicura Chihuailaf, durante uma aula em um de seus cursos:

Un estudiante me dice: ¿Por qué usted insiste tanto em hablar de los chilenos y de los mapuches? ¿Acaso usted no es chileno o no se siente chileno? Le digo: yo nací y crecí en una comunidad mapuche en la que nuestra mirada de lo cotidiano y lo transcendente la asumimos desde nuestra propia manera de entender el mundo: en mapuzungun y en el entonces obligado castellano; en la morenidad en la que nos reconocemos; y en la memoria de la irrupción del Estado chileno que nos "regaló" su nacionalidad. Irrupción constatable "además" en la proliferación de los latifundios entre los que nos dejaron reducidos. Les digo a los estudiantes (ahora también a usted): Imagínense por un instante siquiera, ¿Qué sucedería si otro Estado entrara a ocupar este lugar y les entregara documentos con una nueva nacionalidad iniciando la tarea de arreduccionarlos, de imponerles su idioma de mistificarles - como forma de ocultamiento - su historia, de estigmatizarles su cultura, de discriminarlos por su morenidad? ¿Se reconocerían en ella o continuarían sintiéndose chilenos? (CHIHUAILAF, 1999, p.12).

A invasăo e usurpaçăo dos territórios mapuches se evidenciam neste relato e por outro lado, se escancara a inferiorizaçấo da morenidade como forma de discriminaçâo e controle da naçáo indígena invadida. O híbrido chileno de pele morena, que embora năo se sinta indígena porque sofreu com mais força o processo de deseducaçăo, também se opóe à brancura, pureza e arraigo das altas culturas ocidentais. Contudo, este estado de hibridaçăo cultural em que se encontra irreversivelmente o homem colonizado, conjuga o epistemológico hegemônico ocidental e o epistemológico/ cultural indígena numa tecitura comparada ao entrelaçamento do tear. Nas palavras de Mignolo: "La huella imborrable de lo que existía convertido en herida colonial, en la degradación de la humanidad, en la inferioridad de los paganos, los primitivos, los subdesarrollados, los no-democráticos." (MIGNOLO, 2008, p.271).

O autor eleva a voz para denunciar o mecanismo de degradaçâo que o colonizadorconquistador utilizou para inferiorizar as culturas dos povos originários da América pré-hispânica e se apropriar de seus territórios.

De acordo com o poema-cançăo de Violeta Parra, intitulado "Arauco tiene una pena", o metal, que para os povos originários, mapuches, nahualt ou quéchuas, simbolizava o resplandecer do seu Deus Sol, em seu quinto nível, o qual possuía um valor incalculável, pois preservava a própria vida na Terra, para os espanhóis só representava riqueza material, e por ele matava sem piedade, como podemos ler no excerto do poema:

Un día llega de lejos

Huescufe conquistador

Buscando montañas de oro

Que el indio nunca busco

$\mathrm{Al}$ indio le basta el oro

Que le relumbra del Sol

¡Levántate, Curimón! 


\author{
Entonces corre la sangre \\ No sabe el indio qué hacer \\ Le van a quitar su tierra \\ La tiene que defender \\ El indio se cae muerto \\ Y el afuerino de pie \\ ¡Levántate, Manquilef!
}

(PARRA, 1966).

Para a Europa esse metal de cor amarela brilhante representava riqueza material, era necessário acumulá-lo, guardá-lo em cofres devido ao seu caráter extinguível. Por isso, na primeira estrofe deste poema cançâo, desponta o motivo econômico pelo qual o conquistador matava os indígenas, buscava "montañas de oro que el indio nunca buscó".

Os versos do poema revelam a intençăo do eu lírico em destacar valores opostos em confronto entre o colonizador e o colonizado: "Al índio le basta el oro que relumbra del sol." Observamos a compreensăo da dualidade do mundo indígena, em oposiçâo a valores que correspondem ao agir mercantilista do conquistador.

Na estética destas formas folclóricas habita uma poética arcaica, enraizada nas vozes dos cantores populares como reminiscências de um tempo pré-colonial, mas também, se escuta o lamento dos povos mapuches despojados da sua liberdade de acreditar em suas próprias divindades e possuir uma espiritualidade diferente que olha sempre ao oriente, nunca ao Norte.

O ouro que vem do Sol reflete seu brilho sobre o mundo dos homens e nisto reside a compreensâo do universo em harmonia. Para os mapuches, esses elementos da natureza estavam associados a uma compreensăo de natureza totêmica.

De acordo com a cultura mapuche, existe uma dualidade cósmica, na qual o homem pertence e há que estar consciente dela para preservar o equilíbrio de todos os elementos essenciais que constituem a vida, porque dele depende a continuidade da vida, da Terra e do Universo. Năo quebrar a harmonia é manter-se vivo. A obra poética mapuche é corpórea. A dualidade presente no homem ancestral, se manifesta na sua natureza constituída de alma e corpo. Violeta capta essa essência corpórea e dual e as transfere a sua poesia.

Violeta Parra, em seu canto mapuche, convoca a levantarem-se de seus túmulos, os caciques Huenchullán, Curimón e Manquilef, todos nomes totêmicos que mantém a estirpe de suas geraçóes, que morreram lutando pelo direito a serem indígenas e de preservarem sua cultura. Homens que se negaram a aceitar a imposiçáo cultural do conquistador.

A poeta revela que o ouro năo simbolizava para os indígenas poder econômico e riquezas, este símbolo faz parte da cultura ocidental e tem uma importância tăo forte na vida daqueles que vem de fora, o conquistador, que por ele săo capazes de matar e morrer: "corre o sangue do índio", que defende a terra. Para o índio, em oposiçấo a esta questăo material, que objetiva a riqueza individual dos europeus, principalmente, da 
Coroa e do Clero, o que lhe preocupa é a terra, como ser pertencente a ela, numa relaçáo amorosa de um filho que ama a sua máe.

Elicura Chihuailaf fala sobre a relaçăo vital do povo mapuche com a terra:

Vagando entre riachuelos, bosques y nubes veo pasar las estaciones: Brotes de Luna fría (invierno), Luna del verdor (primavera), Luna de los primeros frutos (fin de la primavera y comienzos del verano), Luna de los frutos abundantes (verano), y Luna de los brotes cenicientos (otoño). Salgo con mi madre y mi padre a buscar remedios y hongos. [...]Aprendo entonces los nombres de las flores y de las plantas. Los insectos cumplen su función. Nada está de más en este mundo. El universo es una dualidad, lo positivo no existe sin lo negativo. La tierra no pertenece a la gente. Mapuche significa gente de la tierra - me iban diciendo. (CHIHUAILAF, 1999, p.19).

"Gente de la tierra" se opóe a dono da terra. Ao sentido de posse do colonizador de indexar terras para a Coroa. A terra A Nuke Mapu, que significa "Măe da Terra" em castelhano, está intimamente relacionada ao movimento que possibilita as diferentes estaçóes do ano. Nesta acepçăo, para o povo mapuche, a terra tem um sentido mais profundo, náo se refere ao solo, ou ao planeta Terra, unicamente e de forma isolada. A terra năo pertence aos homens, esse conceito está interrelacionado às crenças do povo mapuche. Através dos Ngen ou espíritu da natureza, em conjunto com Antü, "O Pai Sol”, a terra entrega constantemente a vida ao povo mapuche. Isto implica na relaçấo de reciprocidade que existe entre o ser mapuche e a terra. A magia, o respeito, a devoçáo, a forma poética com que esse povo se interrelaciona com a terra é fundamental para manter o equilíbrio de seu ecossistema. Violeta Parra captou estas formas poéticas plenas de conteúdo em conversaçăo com a Machi Maria Painên Cotaro, e desde esse momento, sua obra se transforma.

Em Violeta se fue a los cielos (2006), Ángel Parra, o filho, explica como Violeta aprendeu a interpretar a cultura indígena mapuche do sul do Chile.

Una mañana vi salir a mi madre con una inmensa maleta. Pregunté: 'mamita, ¿Qué lleva ahí?'. 'Ropa', me contestó, 'ropa para los mapuches. Me ausentaré algunos días, cuida la casa' [...] Algunos días después, un taxi, [...] se detuvo en la puerta. [...] Bajó mi mamá del auto con su guitarra y una extraña caja gris [...]: era una máquina grabadora nueva. La vi feliz. Una vez dentro de casa conectó el aparato mágico y me dijo: 'escucha'. De esta máquina maravillosa salió la voz de una anciana que repetía y repetía lo que yo recuerdo como puyu puyu peti ré puyu puyu puyu peti ré, muchas veces. Sentí primero sopor, luego mareo. La voz acompañada de un kultrún era de María Painén Cotaro. Nunca olvidé su nombre. Meica, curandera, machi, chamana, araucana. Rogativas, oraciones, no sé lo que contenían esos cantos. Acto seguido se puso de pie y me mostró los pasos de danza ritual con los que se acompañaba la invocación. (PARRA, Ángel, 2006, p.117-18).

Este relato, a princípio foi tomado sem muita importância, apenas como uma evidência de que Violeta havia tido algum contato com o povo mapuche, isso explica a presença indígena em seu último álbum com várias cançôes que remetem a esse povo ancestral. Isso explica, também, os elementos de repetiçâo nos versos de "El Gavillan", como expressa Paula Miranda: 
Hay muchos rasgos en la dimensión formal de la música y el canto que permiten vincular a plenitud sus realizaciones con los de los ül que ella recopiló y con los rituales que presenció en la ruka de María Painen Cotaro o más tarde en Arauco. Aquí destacaremos tres esenciales. El primero y problamente el más importante sea el trabajo con la voz. Violeta ha escuchado y grabado durante varios meses las voces de las cantoras y al ülkantufe López Quilapan; en todas ellas trasuntan una enorme emotividad, inflexiones de sufrimiento y sentimentalidad, pero sin jamás caer en tonos melodramáticos. A veces el ül se transforma en un suspiro, en un quejido o lamento, en una oración. Esa sonoridad sin duda ha quedadeo registrada en la voz que está detrás de "El gavillan" y que la misma Violeta imaginó en ese registro. (MIRANDA, 2017, p.71).

Elicura Chihuailaf reflete sobre quais săo as verdadeiras necessidades de seu povo:

Sentado en las rodillas de mi abuela oí las primeras histórias de árboles y piedras que dialogan entre sí, con los animales y con la gente. Nada más me decía, hay que aprender a interpretar sus signos y a percibir sus sonidos que suelen esconderse en el viento. (CHIHUAILAF, 1999, p.17).

Năo sabemos mais interpretar os signos e moramos perdidos num mundo que nâo consegue dialogar com esses novos interesses que vieram de fora. Mas a falta de ostentaçăo de riquezas materiais, de consumo arbitrário dos recursos naturais, erroneamente foi interpretada pelos colonizadores como pobreza de ideais e poder social. Além disto, diz Chihuailaf:

El lenguaje de la naturaleza es un todo, claro/ transparente, así como en su esencia lo es el lenguaje de los seres humanos. ¿Qué ha ocorrido entonces con la palabra? ¿Qué ha ocurrido con la melodía azul del entendimiento/sabiduría que le da la vida? Si nos referimos ahora a su espíritu y no solo a su forma, ¿podríamos decir que se ha enturbiado en conceptos como superioridad, orgullo, salvaje, conquista, patria? ¿Y sobre todo con el ocultamiento o tergiversación-según sea el caso- de las significaciones, asumidas desde las diversas perspectivas de mundo, de conceptos como civilización, desarrollo y modernidad? (CHIHUAILAF, 1999, p.41).

Na obra de Violeta Parra, esses pontos sâo colocados com o intuito de desarticular o binarismo assimétrico ocidental, no qual se sustentam os mecanismos de dominaçâo colonialista. Tais mecanismos afetavam e afetam à continuidade da tradiçáo popular, por considerá-la expressāo de uma cultura empobrecida a causa do sistema. Violeta Parra evidencia, de que maneira, as formas simbólicas săo empregadas e articuladas para mobilizar os sentidos (significados), em contextos específicos, e deste modo, propiciar o estabelecimento de relaçóes de dominaçáo.

Paula Miranda analisando o poema cançâo "Arauco tiene una pena" ou "Levántate Huenchullán"5 - como Violeta o havia intitulado no início - comenta que, se encontra no caminho da reivindicaçâo e da crítica social, com que Violeta afronta a usurpaçâo de que foi vítima o povo mapuche. A pesquisadora, citando a interpretaçăo da neta

5 “Gravada na primeira versāo como “Levántate Huenchullán”, em 1962, na Argentina, no disco El folklore de Chile según Violeta Parra". (MIRANDA, 2017, p.165). 
de Violeta, Tita Parra, comenta que em suas sete estrofes, a artista faz referência ao calvário inevitável pelo qual devia passar o povo mapuche e que deveria seguir padecendo esse povo indígena com a herança colonialista que carregam os chilenos, o qual termina com uma chamada ao levantamento de seus longko.

Por se tratar de uma produçâo poemática, é possível, ainda realizar outras leituras deste poema, uma delas, poderia ser fundada no sentido da esperança. Nos últimos versos, a poeta afirma com veemência "totora de cinco siglos, nunca se habrá de secar", tornando evidente a convicçâo que a artista tinha, de que o povo mapuche teria sofrido um processo de ocultamento, silenciamento, mas os colonizadores nunca conseguiram secar sua força, suas convicçóes, sua cultura, pois ela cresce mesmo afundada na água, como a Totora. Essa forma poética de enxergar o mundo os ajudaria a preservar suas vidas.

O conceito de "civilizaçăo", o qual se opôe ao conceito de "cultura", assim como, ao conceito de "selvagem", como foram qualificados os povos indígenas, estâo sendo questionados pelo povo mapuche. Na acepçáo que toma com a conquista, "selvagem" é considerado "inculto. "Persona que se porta sin consideración con los demás, o de manera cruel e inhumana. Violento e incontrolable, o que hace ostentación de fuerza". (CHIHUAILAF, 1999, p.41).

Por este motivo, no escudo de armas do Estado do Chile, lembra Chihuailaf, que em 1819, foram trocados os métodos de "civilizaçáo" dos indígenas por uma advertência "Por la razón o la fuerza", após ter passado por um processo violento de desvalorizaçăo, discriminaçâo por sua "morenidad". A mesma discriminaçăo que tomou parte da vida e da história de Violeta Parra, por ser morena e de rasgos indígenas.

E tanto lhe afetou a imagem a Violeta, que ela descreve o preconceito contra o indígena, o mestiço e o pobre, todos necessariamente morenos, em sua autobiografia, mostrando esse jogo de imagens "pulcras", "belas", bem-vestidos dos poderosos, que provocavam a curiosidade e de alguns até admiraçăo ao ver nesses símbolos de grandeza, essas imagens se revelando na sua frente como a materializaçăo de sua aspiraçăo mais profunda, a de deixar de ser colonizado para ser "admirado" como o colonizador.

Em oposiçăo a esse discurso civilizatório, nas Décimas Autobiográficas em verso (1970), Violeta descreve um quadro nada civilizador: "hormigueando, chiquillos copuchentos e to'o mugrientos". (PARRA, 1970:56.), com relaçăo às crianças em bandos como formigas, curiosas e sujas, fazendo referência às crianças pobres das favelas, quando sâo visitados por alguma autoridade em carros oficiais nos quais gastam o dinheiro público. A esse grupo pertencia seu avó paterno. Nesses "chiquillos copuchentos" estâo incluídos os filhos dos indígenas e mestiços que trabalhavam nos latifúndios, os quais estavam instalados no território indígena, pois toda a regiăo de Temuco, Lautaro corresponde às terras do Wallmapu6.

Entretanto, esse discurso discriminatório que apresenta ironicamente Violeta, é fundador dos preconceitos baseados nas diferenças culturais entre povos originários da América e culturas herdadas das metrópoles.

$6 \quad$ Territorio mapuche localizado ao sul do Chile entre San Carlos onde nasceu Violeta na província de Nuble e a cidade de Temuco, segundo mapa apresentado no livro Violeta Parra en el Wallmapu (2017). 


\section{CONSIDERAÇÕES FINAIS}

Na produçăo de Violeta Parra, artista e obra formam uma unidade. Como artista contemporânea ela se vincula ao povo, entra em cena, cria a figura da artista como personagem. Violeta vivenciava a personagem que ela mesma havia criado: a artista popular alheia a toda modernidade que se opunha radicalmente à sociedade burguesa. Neste sentido, desejando criar uma personagem náo contaminada pela burguesia em sua própria imagem, Violeta se transforma, a si mesma em uma mulher de campo, que possui o saber popular das tradiçóes culturais ancestrais dos povos originários da América e arcaicas da Espanha.

Seguindo esta ideia, talvez, ainda sem uma consciência da dimensăo que tomaria sua obra, nasce e amadurece a folclorista, que passa a compreender a história do Chile e os processos de transculturaçấo que afetaram os povos originários da América. Isto fica evidente no ritmo mapuche que ela reproduz nos versos das cançôes poemas contempladas nas Últimas Composiciones (1966).

A obra poético-musical de Violeta Parra contempla esta mensagem e por isso é possível compreender, no conjunto artístico, um tecido dialógico, no qual se entrelaçam de maneira profunda outros mundos, outras culturas, outros idiomas e sua poética de resistência à colonialidade do poder.

A arte de Violeta Parra desloca os limites dos modelos que a ciência das belas artes e das obras poético-musicais clássicas estabelecem como depositárias da razáo ocidental, concebida como o único meio válido de pensar e produzir arte. Resistência e ruptura respondem à necessidade da artista de contribuir para emancipar cultural e epistemologicamente a tradiçăo popular. Um olhar para estes poemas justifica-se no intento de dar visibilidade à opçấo decolonial, advinda da assimilaçâo da vertente de tradiçấo popular, a vertente indígena, presente na obra de Violeta Parra, a qual provoca mudanças profundas que conduzem à maturidade artística como poeta e artista plástica emancipada, mulher do povo consciente que compreende e assume seu papel como artista latino americana e a funçăo emancipatória de sua arte. 


\section{REFERÊNCIAS}

CHIHUAILAF, N. E. El libro de los sueños azules y contrasueños. Santiago de Chile: Ed.Universitaria e Ed. Cuarto Propio.1999.

LIENHARD, M. La voz y su huella. La Habana, Cuba: Casa de las Américas, 2011.

MIGNOLO, W. Historias locais. Projetos globais: colonialidade, saberes subalternos e pensamento limiar. Trad. Solange Ribeiro de Oliveira. Belo Horizonte: Editora UFMG, 2008.

MIRANDA, P. La Poesía de Violeta Parra. Santiago de Chile: Cuarto Propio, 2014.

MIRANDA, P.; LONCON, E.; RAMAY, A. Violeta Parra en el Wallmapu, su encuentro con el canto mapuche. Santiago de Chile, Ed. Pehuén, 2017.

PARRA, Á. Violeta se fue a los cielos. Santiago de Chile: Catalonia, 2006.

PARRA I. El libro mayor de Violeta Parra: Un relato biográfico y testimonial. Santiago de Chile: Cuarto Propio, 2009.

PARRA, V. Últimas Composiciones de Violeta Parra. Santiago de Chile, RCA Victor CML: 2456, LPVE, 4766-1, 1966.

Décimas. Autobiografía en versos. Santiago de Chile: Ed. Nueva Universidad, 1970. PIN̂A, J. A. 21 Son los Dolores: Violeta Parra Antología amorosa.

Santiago de Chile: Aconcagua, 1978.

SOUBLETTE, G. Cantos Folclóricos Chilenos. Santiago de Chile: Ed. Ceibo, 1979.

SUBERCASEAUX, B.; STAMBUK, P.; LONDOÑO, J. Gracias a la Vida: Violeta Parra, testimonio. Santiago de Chile: Granizo/ CENECA, 1978. 